\title{
Foreword
}

\section{THE CANADIAN ASSOCIATION OF CHIEFS OF POLICE}

In August 1987, the Board of Trustees of the Canadian Association of Chiefs of Police ( $\mathrm{CACP}$ ) Research Foundation approved a proposal to have a history written of the association. This proposal had been received from Greg Marquis, Department of History, Queen's University, Kingston, Ontario.

Pursuant to the Board of Trustees' approval, terms of reference for the history were subsequently approved, and the $\mathrm{CACP}$ Research Foundation committed the sum of $\$ 5,000$ to cover the cost of research and related costs to prepare the history. Prior to this commitment, there existed no documentation that in any way systematically recorded the development of the CACP as a national association. An earlier attempt, in the mid1970 s, to have a history of the CACP researched and written by a historian/ consultant met with a number of problems and had to be abandoned. Nevertheless, a number of long-time CACP members who were particularly active in the association continued to express an interest in such a project. Consequently, when Greg Marquis made his proposal, it was welcomed and approved.

Greg Marquis, PhD in history, Queen's University, has proved to be an excellent choice to research and write the history of the CACP. His MA thesis, 'The Police Force in Saint John, New Brunswick, 1860-1890' (1982), together with his contribution to a book on the history of Charlottetown, PEI, entitled 'Enforcing the Law: The Charlottetown Police Force' (1988), as well as other writings in the domain of criminal justice, attest to his 


\title{
viii Foreword
}

competence as a historian. Greg Marquis applied himself diligently to the task and, with the assistance of CACP staff and various police forces across Canada, was able to thoroughly research and write this history of the CACP.

The CACP is particularly pleased that the University of Toronto Press agreed to publish this work. Those reviewing the manuscript noted that the document went beyond simply recording the history of the CACP as an institution, focusing, as well, on the concerns and preoccupations of Canada's police chiefs through the years. Thus it comes close to being a history of policing in Canada. Consequently, the title, Policing Canada's Century: A History of the Canadian Association of Chiefs of Police, was readily agreed to and adopted.

In 1992, the Board of Trustees of the CACP Research Foundation gave their approval to a co-publication arrangement with The Osgoode Society, which regards this work highly and will be making it available, as part of the Society's Legal History series, to its members across Canada. In their view, it will serve to contribute to a better understanding on the part of Canada's lawyers of the historic role of the CACP, the police, and policing in Canada.

This book is a pleasure to read. It traces, chronologically and thematically, the role of the $\mathrm{CACP}$ as a substitute for a 'national' policy-making institution for municipal (and, to a lesser extent, provincial) police forces, which has never existed in Canada. At the same time, important facets of the role of the Royal Canadian Mounted Police and its predecessors are discussed in considerable detail.

I highly recommend this publication to all CACP members, and to anyone who has an interest, professional or otherwise, in the history and development of the CACP and policing in Canada.

\author{
Alain St-Germain \\ Director, Montreal Urban Community Police Service \\ President, Canadian Association of Chiefs of Police
}

